\title{
Magnitude of Obesity/Overweight and lts Associated Factors Among HIVIAIDS Patients on Antiretroviral Therapy in Jimma Zone Hospitals, South West Ethiopia: Hospital-Based Cross-Sectional Study
}

This article was published in the following Dove Press journal:

Diabetes, Metabolic Syndrome and Obesity: Targets and Therapy

Getachew Yideg Yitbarek, (iD) Melaku Tadege Engidaw, (D) ${ }^{2}$ Belete Achamyelew Ayele, ${ }^{3}$ Sofonyas Abebaw Tiruneh, (iD ${ }^{4}$ Melkamu Tilahun Alamir ${ }^{5}$

'Department of Biomedical Sciences (Medical Physiology), College of Health Sciences, Debre Tabor University, Debre Tabor, Ethiopia;

${ }^{2}$ Department of Social and Public Health (Human Nutrition), College of Health Sciences, Debre

Tabor University, Debre Tabor, Ethiopia; ${ }^{3}$ Wogeda Primary Hospital, Amhara Regional Health Bureau, Bahir Dar, Ethiopia; ${ }^{4}$ Department of Social and Public Health (Epidemiology), College of Health Sciences, Debre Tabor University, Debre Tabor, Ethiopia; ${ }^{5}$ Department of Biomedical Sciences (Medical Physiology), College of Health Sciences, Debre Markos University,

Debre Markos, Ethiopia

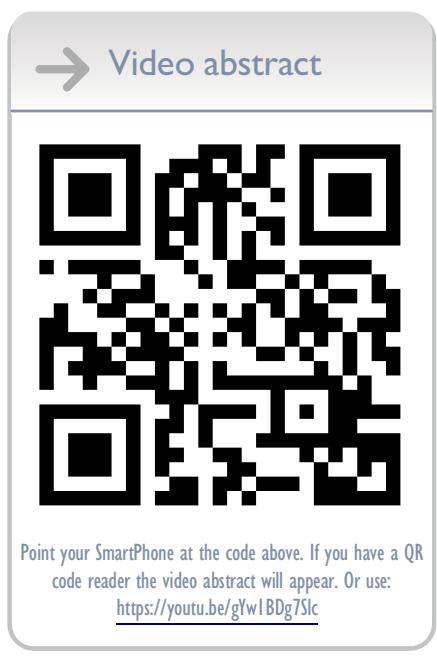

Correspondence: Getachew Yideg Yitbarek

Debre Tabor University, Po Box: 272,

Debre Tabor, Ethiopia

Tel +25l 921748502

Email getachewyideg@gmail.com
Purpose: Obesity is on the rise worldwide, not only in the general population but also in PLWHA. Being overweight and obese are themselves risk factors for cardiovascular and other diseases. Despite this, few studies have been conducted to determine the magnitude of obesity/overweight and its associated factors among HIV/AIDS patients in Ethiopia, which necessitates this study.

Methods: Hospital-based cross-sectional study was conducted from December to January 2019 at selected Jimma zone hospitals. WHO STEP-wise approach to chronic disease risk factor surveillance (STEPS) questionnaire and document review for HIV-related clinical factors was applied. Weight, height and waist circumference and hip circumference were measured. Data were analyzed using SPSS version 20.

Results: A total of 252 participants with a response rate of $95.8 \%$ were included. The prevalence of obesity/overweight was $21 \%$. After adjusting for these variables, age category of greater than 50 years $[\mathrm{AOR}=0.4,95 \% \mathrm{CI}(0.2,0.9), \mathrm{p}=0.03]$, WHO clinical stage III and above $[\mathrm{AOR}=0.04,95 \% \mathrm{CI}(0.002,0.6), \mathrm{p}=0.02]$, presence of mild to moderate physical activity $[\mathrm{AOR}=1.3,95 \% \mathrm{CI}(5.5,33.3), \mathrm{p} \leq 0.001)]$, plasma CD4 count between 351 and 500 copies $/ \mathrm{mL}$ [AOR $=0.15,95 \%$ CI $(0.04,0.6) \mathrm{p}=0.024]$, and female sex [AOR $=2.6,95 \% \mathrm{CI}(1.25,10) \mathrm{p}=0.03)]$ were significantly associated with obesity/overweight.

Conclusion: There was a high prevalence of obesity/overweight among HIV/AIDS patients. It was found that older age, female sex, early stage of the disease, lower CD4 count and presence of mild to moderate physical activity were significant predictors of obesity/overweight. Clinicians should be aware of the health consequence of obesity and consider instituting targeted weight management programs as a part of routine HIV care.

Keywords: overweight, HIV/AIDS, associated factors, Ethiopia

\section{Introduction}

Obesity is a medical condition in which excess body fat has accumulated to the extent that it may have an adverse effect on health. ${ }^{1}$ Weight gain in HIV-infected patients appears to reflect improved health status, as severe weight loss and wasting has been traditionally associated with HIV-infected status. Highly active antiretroviral therapy has drastically reduced the number of deaths and AIDS-defining events among HIV-infected people, including wasting syndrome. Nowadays, HIVinfected patients who receive combined antiretroviral therapy (cART) live longer. ${ }^{2,3}$ 
However, as seen in the general population, HIV-infected patients also show an association between weight excess and adverse medical consequences. ${ }^{4}$ Indeed, obesity leads to the onset of metabolic imbalances. Central adiposity is associated with the metabolic syndrome and related risks for type 2 diabetes mellitus (DM), atherosclerosis, Dyslipidemia, hypertension and malignancies. ${ }^{5}$

Multicenter HIV Epidemiology Research (HER) Study examined the association of body mass index (BMI) and HIV disease outcomes and followed longitudinally and reported that the mean $\mathrm{CD} 4+$ cell count was progressively higher and the mean log HIV viral load progressively lower as the BMI increased, with no significant difference in age, duration of HIV positivity, income or education by BMI weight group. ${ }^{1}$

The scale-up of HIV treatment and care services in the world and sub-Saharan Africa (SSA) has resulted in a large increase in the number of patients on antiretroviral therapy and their survival rate. Increased survival predisposes HIVpositive individuals to conditions associated with aging. A study done in USA showed Overweight and obesity affected $22 \%$, and $5 \%$ of HIV/AIDS patients who are on HAART respectively. ${ }^{3}$ Several studies have described increasing proportions of overweight and obesity in people living with HIV/AIDS in SSA. ${ }^{6}$ In a large cross-sectional study in Dare Salaam, Tanzania, it was found that $18 \%$ of HIV-positive individuals were overweight and $7 \%$ were obese. ${ }^{7}$

Another study in south Africa found the prevalence of overweight as $26.2 \%$ and obesity as $46.4 \%$, while in ivory coast it was found that $19.7 \%$ of them were overweight, and $7.2 \%$ were obese. ${ }^{8,9}$ In our country Ethiopia, particularly in Addis Ababa showed the prevalence of obesity/ overweight were $27.9 \% .{ }^{10}$ Another study in Ethiopia done in southern Ethiopia showed the prevalence of overweight and obesity were $19.2 \% .^{11}$

On previous study it has been found that obesity and overweight were associated with female sex, age, physical activity level, High blood pressure, clinical stage of the disease, HIV follow-up duration and Hemoglobin level. Moreover, obesity seems to have a detrimental effect on immune recovery after cART initiation. ${ }^{2}$

Being overweight and obese are themselves risk factors for cardiovascular morbidity and mortality and they are also often associated with hypercholesterolemia, hypertriglyceridemia, type 2 diabetes, insulin resistance and degenerative disease of the joint such as osteoarthritis. ${ }^{12,13}$ WHO has issued warnings predicting the emergence of cardiovascular pathologies in resource-limited countries over the coming decades, especially due to the rise in risk factors such as being overweight and obese. ${ }^{14}$ Despite this, data on the progression of body mass index (BMI) and magnitude of overweight and obesity among HIV/AIDS patients on HAART in Ethiopia particularly in the study area are scarce and have been studied less extensively.

\section{Patients and Methods Study Area and Period}

The study was conducted at Jimma zone hospitals antiretroviral (ART) clinic, Jimma zone. Jimma zone is one of the zones in Oromia regional state of Ethiopia. The central city, Jimma is located 352 kilometers Southwest of Addis Ababa, Ethiopia. JUSTH is one of the hospitals among other 5 district hospitals where the data were collected that provide ART services for PLWHA coming from different areas. Institution-based cross-sectional study was conducted at ART clinic of the different hospitals from December to January 2019.

\section{Population and Eligibility Criteria}

The source populations of this study were all HIV/AIDS clients enrolled to ART clinic of the six hospitals. While sample of HIV/AIDS patients attending at ART clinic during the study period were our study population. Those patients with age greater than 18 and having documented HIV-positive status were included in the study. Those who are pregnant women, mental illness, seriously ill and those with spinal problem and known diabetic patients have been excluded from the study.

\section{Sample Size and Sampling Procedure}

The actual sample size was determined by using the single population proportion formula where the following were considered: $95 \%$ confidence interval, $19.2 \%$ proportion of obesity/overweight among HIV positive clients ${ }^{11}$ and 5\% margin of error. Added 10\% estimated non-response rate that made a final sample size of 263. The sample was proportionally allocated to each district hospitals (6 hospitals) found in Jimma zone. The participants were selected through systematic random sampling technique after having the monthly client flow of each hospital.

$$
\begin{aligned}
& \mathrm{n}=\frac{(Z \alpha / 2)^{2} \times p(1-p)}{\mathrm{d}^{2}}=\frac{(1.96)^{2} \times(0.192 \times 0.808)}{(0.05)^{2}} \\
& \mathrm{n}=239
\end{aligned}
$$

Adding 10\% non response rate and using correction formula the final sample size was 263 . 


\section{Operational Definition}

Generalized Obesity was referred to a patient with a BMI of greater than 30 , While Central obesity was referred to a patient with a WHR of greater than 0.95 for males and greater than 0.85 for females. Overweight was referred for a patient with BMI between 25 and 30 .

\section{Data Quality Control}

The questionnaire was translated into local language (Amharic and Afan Oromo) from its English version then back to English with the guidance from nutritionists. Training was provided for the data collectors for one day on how the data should be obtained and recorded. Pre-test was done on 14 HIV positive clients at Shenen Gibe primary Hospital before the actual data collection time in order to see the validity of the instrument, to estimate the time needed to collect data, and to modify the questionnaire accordingly. Data collectors were supervised while collecting the data by the principal investigator and technical support was provided accordingly. Data were checked daily for completeness and consistency throughout the data collection period.

\section{Data Collection}

A total of three data collectors (three nurses from ART clinic) were employed to collect data. A structured pretested questionnaire was adapted from the WHO STEP wise questionnaire for Chronic Disease Risk Factor Surveillance was used in this study. ${ }^{15}$ Data about physical activity were collected for a week duration based on the WHO STEP wise approach to chronic disease risk factor surveillance (STEPS) questionnaire and document review for HIV related clinical factors. Data collectors measured weight (to the nearest $0.1 \mathrm{~g}$ ), height, hip and waist circumferences (to the nearest 0.1centimeter), and BP (to the nearest $0.5 \mathrm{mmHg}$ ) of interviewed participants whose data were kept anonymous. Body mass index and waist to Hip ratio of the participants were calculated.

\section{Data Analysis}

Data were edited, coded, and entered into Epi Data version 3.1 and then exported to SPSS version 20 for analysis. Descriptive summary using frequencies, proportions, graphs and cross tabs were used to present study results. Odds ratio (OR) and confident interval (CI) was used to determine the strength of association between independent and dependent variables. Bivariate analysis was performed separately using binary logistic regression to rank the relative importance of exposure variables with outcome variable using crude odds ratios. The variables that have statistically significant ( $P$ value of $\leq 0.25$ ) associations with the outcome variable in the bivariate analysis were further considered a candidate for stepwise multiple logistic regression model to control the effect of confounding variables. Finally, those variables with $\mathrm{P}$-value less than 0.05 on multiple logistic regression were considered as statistically significant.

\section{Results}

The study involved 252 HIV/AIDS patients who are on HAART in Jimma zone hospitals. This makes the response rate of the respondent $95.8 \%$. Of the study Participants $144(57.1 \%)$ was females. Majority of the study participants were in the age group of 31-50 years with 104 (41.3\%). The mean age of the study participants were $37.9( \pm 9.7)$ years. The mean BMI was $22.2 \mathrm{~kg} / \mathrm{m} 2$ $( \pm 5.2)$. About $69.4 \%$ had performed mild to moderate physical activity (Table 1).

\section{Clinical Parameters of HIVIAIDS Clients, Jimma Zone Hospitals}

The mean duration of HAART follow-up was 2.1 years (SD \pm 1.1 ). Among 252 participants, about 134 (53.2\%) were on HAART follow-up for 5 or more years, while 45 $(17.9 \%)$ of them were on follow-up for less than two years. The mean CD4 counts of the participants were $403.1 \pm 240.1$. In addition, the recent CD4 of the participants was greater than 500 cells $/ \mu \mathrm{L}$ and less than 200 cells $/ \mu \mathrm{L}$ for about $31.3 \%$ and $30.2 \%$ of the participants, respectively. Co-morbid hypertension was observed in $22.6 \%$ of the participants. Plasma viral load status of the participants showed $134(53.2 \%)$ of them had undetectable viral replication (less than 50 copies/ul of blood (Table 2).

\section{Nutritional Status of HIVIAIDS Patients at Jimma}

In the analysis, the prevalence of generalized overweight/ obesity was $21 \%, 95 \%$ CI $(16.3,26.2) .19 \%$ of them were overweight and $2 \%$ of them were obese. Under nutrition (Chronic Energy deficiency) among HIV/AIDS Clients on ART was $11.9 \%$, while 169 (67.1\%) of the participants had BMI in the normal range (BMI 18.5-24.9 Kg/m2). The prevalence of abdominal obesity was $38.7 \%$ in females and $16.4 \%$ in males (Figure 1). 
Table I Demographic Characteristics of HIV/AIDS Patients on HAART at Jimma Zone Hospitals, Ethiopia, 2019

\begin{tabular}{|c|c|c|c|}
\hline Characteristics & Variables & Frequency & $\begin{array}{l}\text { Percent } \\
\text { (\%) }\end{array}$ \\
\hline Age (years) & $\begin{array}{l}18-30 \\
31-50 \\
\geq 50\end{array}$ & $\begin{array}{l}68 \\
104 \\
80\end{array}$ & $\begin{array}{l}27 \\
41.3 \\
31.7\end{array}$ \\
\hline Sex & $\begin{array}{l}\text { Female } \\
\text { Male }\end{array}$ & $\begin{array}{l}144 \\
108\end{array}$ & $\begin{array}{l}57.1 \\
42.9\end{array}$ \\
\hline Educational Status & $\begin{array}{l}\text { Below } \\
\text { elementary } \\
\text { education } \\
\text { High school } \\
\text { College and } \\
\text { above }\end{array}$ & $\begin{array}{l}132 \\
68 \\
52\end{array}$ & $\begin{array}{l}52.4 \\
\\
27 \\
20.6\end{array}$ \\
\hline Marital Status & $\begin{array}{l}\text { Single } \\
\text { Married } \\
\text { Divorced } \\
\text { Widowed }\end{array}$ & $\begin{array}{l}46 \\
134 \\
37 \\
35\end{array}$ & $\begin{array}{l}18.3 \\
53.2 \\
14.7 \\
13.9\end{array}$ \\
\hline Occupation & $\begin{array}{l}\text { Government } \\
\text { employed } \\
\text { Merchant } \\
\text { House wife } \\
\text { Daily laborer } \\
\text { Others }\end{array}$ & $\begin{array}{l}84 \\
63 \\
17 \\
14 \\
7\end{array}$ & $\begin{array}{l}33.3 \\
\\
24.2 \\
5.2 \\
5.6 \\
2.8\end{array}$ \\
\hline Monthly Income & $\begin{array}{l}<2000 \\
\geq 2000\end{array}$ & $\begin{array}{l}89 \\
163\end{array}$ & $\begin{array}{l}35.4 \\
64.6\end{array}$ \\
\hline $\begin{array}{l}\text { Mild to Moderate } \\
\text { Physical Activity }\end{array}$ & $\begin{array}{l}\text { Yes } \\
\text { No }\end{array}$ & $\begin{array}{l}175 \\
77\end{array}$ & $\begin{array}{l}69.4 \\
30.6\end{array}$ \\
\hline Residence & $\begin{array}{l}\text { Urban } \\
\text { Rural }\end{array}$ & $\begin{array}{l}222 \\
30\end{array}$ & $\begin{array}{l}88.1 \\
11.9\end{array}$ \\
\hline
\end{tabular}

Note: Others - student, farmer, private employee.

\section{Factors Associated with Obesity and Overweight}

All variables that had $p$ value $\leq 0.25$ in the bivariate analysis were included in the multivariable analysis. In the study age, sex, physical activity level, occupational status, monthly income, CD4 count, WHO clinical stage, duration of HAART follow-up and plasma viral load were significantly associated with obesity/overweight status in bivariate analysis. After adjusting for these variables, age category of greater than 50 years $[\mathrm{AOR}=0.4,95 \% \mathrm{CI}(0.2,0.9)$, $\mathrm{p}=0.03]$, female sex $[\mathrm{AOR}=2.6,95 \% \mathrm{CI},(1.25,10)$ $\mathrm{p}=0.03)]$, WHO clinical stage III and above $[\mathrm{AOR}=0.04$, $95 \% \mathrm{CI}(0.002,0.6), \mathrm{p}=0.02]$, presence of mild to moderate physical activity $[\mathrm{AOR}=1.3,95 \% \mathrm{CI}(5.5,33.3), \mathrm{p} \leq 0.001)]$ and plasma CD4 count between 351 and 500 copies $/ \mathrm{mL}$
Table 2 Clinical Characteristics of HIV/AIDS Patients on HAART at Jimma Zone Hospitals, Ethiopia, 2019

\begin{tabular}{|c|c|c|c|}
\hline Clinical Factors & & Frequency & $\begin{array}{l}\text { Percent } \\
(\%)\end{array}$ \\
\hline Comorbid HTN & $\begin{array}{l}\text { Yes } \\
\text { No }\end{array}$ & $\begin{array}{l}57 \\
195\end{array}$ & $\begin{array}{l}22.6 \\
77.4\end{array}$ \\
\hline $\begin{array}{l}\text { Duration of Illness Since } \\
\text { Diagnosis (years) }\end{array}$ & $\begin{array}{l}<3 \\
\geq 3\end{array}$ & $\begin{array}{l}36 \\
2216\end{array}$ & $\begin{array}{l}14.3 \\
85.7\end{array}$ \\
\hline $\begin{array}{l}\text { Current (Most Recent) } \\
\text { CD4 Count (cell/ } / \mathrm{L})\end{array}$ & $\begin{array}{l}<200 \\
200-350 \\
351-500 \\
\geq 500\end{array}$ & $\begin{array}{l}76 \\
38 \\
59 \\
79\end{array}$ & $\begin{array}{l}30.2 \\
15.1 \\
23.4 \\
31.3\end{array}$ \\
\hline Viral Load (copies $/ \mu L)$ & $\begin{array}{l}<50 \\
50-1000 \\
\geq 1000\end{array}$ & $\begin{array}{l}134 \\
79 \\
39\end{array}$ & $\begin{array}{l}53.2 \\
31.3 \\
15.5\end{array}$ \\
\hline Duration of ART (years) & $\begin{array}{l}<3 \\
3-5 \\
\geq 5\end{array}$ & $\begin{array}{l}45 \\
73 \\
134\end{array}$ & $\begin{array}{l}17.9 \\
29 \\
53.2\end{array}$ \\
\hline $\begin{array}{l}\text { Clinical Stage of the Disease } \\
(\mathrm{WHO})\end{array}$ & $\begin{array}{l}\text { Stage I } \\
\text { Stage II } \\
\text { Stage III \& } \\
\text { above }\end{array}$ & $\begin{array}{l}193 \\
21 \\
38\end{array}$ & $\begin{array}{l}76.6 \\
8.3 \\
15.1\end{array}$ \\
\hline
\end{tabular}

$[\mathrm{AOR}=0.15,95 \% \mathrm{CI}(0.04,0.6) \mathrm{p}=0.024]$ were significantly associated with obesity/overweight (Table 3).

\section{Discussion}

The present study showed that the prevalence of obesity/ overweight was $21 \%$. This finding is comparable with previous studies conducted in southern Ethiopia and Tanzania, which showed prevalence of obesity/overweight as $19.2 \%$, and $25 \%$, respectively. On the other hand, the prevalence of obesity/overweight in this study was lower than studies conducted in Ethiopia, USA and South Africa, which showed the prevalence as $27.9 \%, 37 \%$, and $46.4 \%$, respectively. ${ }^{2,8,10}$ The difference of body composition may be due to population difference and the existence of different socio-economic and the use of different BMI cutoff value in the study.

Older age, female sex, lower CD4 count, late WHO stage of the disease and physical activity level were found significantly associated with overweight/obesity after adjustment for covariates (Table 3 ).

Illness of patient within WHO Clinical Stage was one of the significant factors for obesity/overweight in the study. Those patients in WHO Clinical stage 3 and above were $90 \%$ times less likely to be obese than 


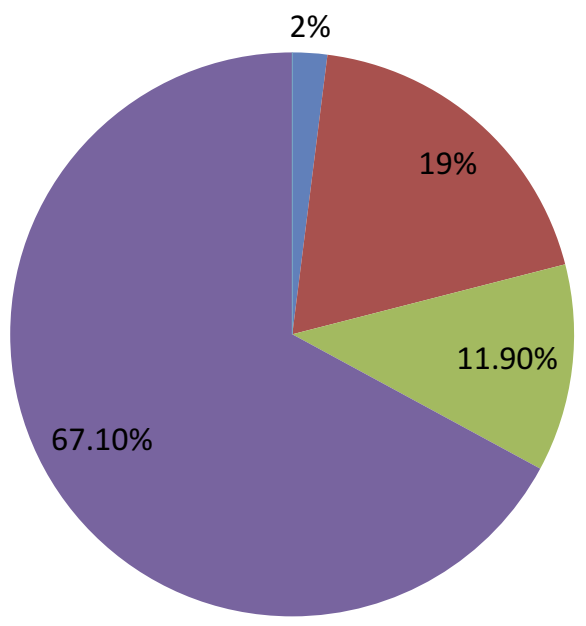

Legend

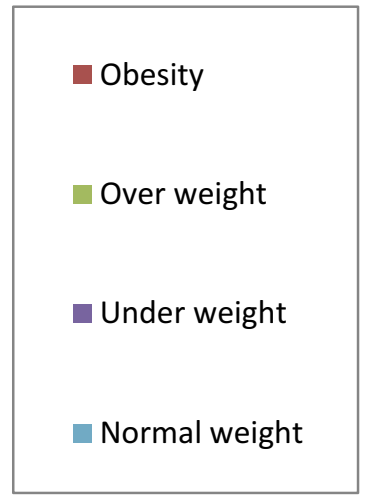

Figure I A pie chart showing nutritional status of the participants at Jimma zone hospitals, 2019.

WHO Clinical stage 1 patients. This is in line with study conducted in Zimbabwe which showed that patients with late stage of the disease are less likely to be obese. But this finding is in contrary with study conducted in southern Ethiopia. ${ }^{16}$
Relative to patients aged greater than 50, patients aged between 18 and 30 , are $60 \%$ times less likely to develop the risk of being overweight $(\mathrm{AOR}=0.4,95 \% \mathrm{CI}(0.2,0.9)$. This is in line with the finding that observed in Tanzania and brazil that showed overweight and obesity were more

Table 3 Final Model Showing Associated Factors of Obesity/Overweight Among HIV-Positive Patients, Jimma Zone Hospitals, Ethiopia, $2019(\mathrm{~N}=252)$

\begin{tabular}{|c|c|c|c|c|}
\hline Variables & Yes $(n=\mid 17)$ & No $(n=2 \mid 3)$ & COR $(95 \% \mathrm{Cl})$ & AOR $(95 \% \mathrm{Cl})$ \\
\hline \multicolumn{5}{|l|}{ Age Category } \\
\hline $18-30$ & $8(15.1 \%)$ & $60(30.2 \%)$ & 1.0 & $0.4(0.2,0.9)$ \\
\hline $31-50$ & $20(37.7 \%)$ & $84(42.2 \%)$ & $0.29(0.1,0.7)$ & $0.38(0.1, I .1)$ \\
\hline$\geq 50$ & $25(47.2 \%)$ & $55(27.6 \%)$ & $0.5(0.3,1)$ & 1.0 \\
\hline \multicolumn{5}{|l|}{ Sex } \\
\hline Female & $19(35.8)$ & $89(44.9)$ & I. $4(0.8,2.5)$ & $2.6(1.25,10)$ \\
\hline Male & $45(64.2)$ & $110(55.3)$ & 1.0 & 1.0 \\
\hline \multicolumn{5}{|l|}{ Physical Activity } \\
\hline Yes & $16(30.2 \%)$ & $159(79.9 \%)$ & 1.0 & 1.0 \\
\hline No & $37(69.8 \%)$ & $40(20.1 \%)$ & $9.2(4.6,18.1)$ & I.3(5.5,33.3) \\
\hline \multicolumn{5}{|l|}{ CD4 Number } \\
\hline$<200$ & $25(47.2 \%)$ & $5 I(25.6 \%)$ & $0.3(0.1,0.9)$ & $0.15(0.04,0.6)$ \\
\hline $20 I-350$ & $8(15.1 \%)$ & $30(15.1 \%)$ & $1.9(0.9,3.9)$ & I.7(0.6,5.3) \\
\hline $35 I-500$ & $4(7.5 \%)$ & $55(27.6 \%)$ & I.I $(0.4,2.7)$ & I.3(0.4,4.5) \\
\hline$>500$ & $16(30.5 \%)$ & $63(31.7 \%)$ & 1.0 & 1.0 \\
\hline \multicolumn{5}{|l|}{ Viral Load(copies $/ \mu L)$} \\
\hline$<50$ & $31(58.5 \%)$ & $103(51.8 \%)$ & 1.0 & 1.0 \\
\hline $50-1000$ & $13(24.5 \%)$ & $66(33.2 \%)$ & $1.0(0.43,2.4)$ & $1.3(0.3,5.1)$ \\
\hline$\geq 1000$ & $9(17 \%)$ & $30(15.1 \%)$ & $0.7(0.3,1.7)$ & $0.7(0.2,2.8)$ \\
\hline \multicolumn{5}{|l|}{ Stage of the Disease } \\
\hline Stage I & $32(60.4 \%)$ & $16 \mathrm{I}(80.9 \%)$ & 1.0 & 1.0 \\
\hline Stage II & $4(7.6 \%)$ & $26(13.1 \%)$ & $0.4(0.1,1.6)$ & $0.2(0.03,1.6)$ \\
\hline Stage III \& above & $17(32.1 \%)$ & $12(6 \%)$ & $0.1(0.01, I . I)$ & $0.04(0.002,0.6)$ \\
\hline
\end{tabular}


prevalent in older patients, with the oldest age-group ( $>50$ years) having the highest burden. ${ }^{17,18}$ This might be due to the relative risk curves of overweight and obesity reach maximum point in the mid-50s and then declines.

On the other hand, this study builds on previous findings that, as in the general population, overweight and obesity among people infected with HIV is more prevalent in women than in men participants. Thus, female participants are 2.6 times more likely to develop obesity/overweight compared to male participants. This is in line with a study on HIV-infected patients in USA which found the prevalence of obesity higher in women than in men. ${ }^{19}$ This could be in fact that male patients with HIV/AIDS in subSaharan Africa tend to begin HIV/AIDS care later than women that would have result loss of more weight than women. This weight loss could be due to, malabsorption, frequent infection, or other, as of yet unknown, physiological factors. On the other side the reason can be explained that females can carry more amount of fat as compared to males.

The magnitude of overweight and obesity was significantly higher among those patients with the highest category of CD4 count. Relative to patients with CD4 counts greater than 500 cells $/ \mathrm{mm} 3$, patients with CD4 counts less than 200 cells $/ \mathrm{mm} 3$ had a reduced risk of obesity. This is in line with other studies conducted in USA. ${ }^{20}$ The association observed might be higher baseline BMI predicts greater gain in CD4 count, including maintenance of immune status and better recovery when patients initiated ART.

The last but not the least physical activity levels of the participants were found significantly associated with obesity/overweight. This study demonstrates that those patients who had no regular mild to moderate physical activity are 1.3 times more likely to develop obesity/overweight compared to those participants with mild to moderate physical activity. This is in line with previous study in south Africa and Rwanda which showed People on ART who were not physically active were more likely to be overweight than those physically active. ${ }^{21,22}$ Physical activity may reduce the risk of being overweight and has a potential anti-inflammatory effect in people on ART. On the other hand more physical activity increases the number of calories your body uses for energy or "burns off." The burning of calories through physical activity, combined with reducing the number of calories you eat, creates a "calorie deficit" that results in weight loss.

\section{Conclusion}

The adverse health consequences of overweight and obesity are well described in the general population and in HIV/AIDS patients. ${ }^{23}$ In this study, we examined patients at HIV follow-up clinic in Jimma zone hospitals, Ethiopia, and found that the magnitude of overweight and obesity were $21 \%$. It was found that older age, female sex, early stage of the disease, lower CD4 count and absence of mild to moderate physical activity were significant predictor of obesity/overweight. Clinicians should be aware of the health consequence of obesity and consider instituting targeted weight management programs as a part of routine HIV care. It is, therefore, vital to encourage intervention strategies that focus on promotion of physical activity among people living with HIV/AIDS.

\section{Limitations of the Study}

Our study is one of a few in Ethiopia to provide information on the problem of obesity/overweight among people on ART in the area. The limitations of this study include its cross-sectional design and the small sample size may limit the inference made. In addition, physical activities were self-reported, and recall bias may have influenced the results.

\section{Abbreviations}

AOR, adjusted odds ratio; BMI, body mass index; WHO, World Health Organization; HIV, human immunodeficiency virus.

\section{Data Sharing Statement}

The authors confirm that all data underlying the findings are fully available without restriction. All relevant data are within the manuscript.

\section{Ethics and Consent Statement}

This study was conducted in accordance with the Declaration of Helsinki. Ethical clearance was obtained from Institutional Review Board, College of Health Science, and Jimma University. Following the endorsement from the university, study setting (ART clinics of the six hospitals) was informed about the objectives of the study through a support letter from the Institutional Review Board. Each participant was then informed about the purpose of the study and his/her right not to participate in the study was respected. Privacy and confidentiality was 
assured. After obtaining informed consent (written) from clients, data was collected.

\section{Acknowledgments}

The authors would like to thank all respondents, the data collectors and supervisors for their willingness to participate in the study.

\section{Author Contributions}

All authors made substantial contributions to conception and design, acquisition of data, or analysis and interpretation of data; took part in drafting the article or revising it critically for important intellectual content; gave final approval of the version to be published; and agree to be accountable for all aspects of the work.

\section{Funding}

There was no funding available for this study.

\section{Disclosure}

The authors declare that they have no conflicts of interest.

\section{References}

1. Shah K, Alio AP, Hall WJ, Luque AE. The physiological effects of obesity in HIV-infected patients AIDS \& Clinical Research. $J$ AIDS Clin Res Shah. 2012;3(4):6. doi:10.4172/2155-6113.1000151

2. Cano CE, Lions C, Zaegel-faucher O, Orticoni M, Saout A, Poizotmartin I. Risk factors associated with overweight and obesity in HIVinfected people. Medicine (Baltimore). 2018;23(5):5.

3. Koethe JR, Jenkins CA, Lau B, et al. Rising obesity prevalence and weight gain in the United States and Canada. AIDS Res Hum Retroviruses. 2016;32(1):8. doi:10.1089/aid.2015.0147

4. Hyman C, Hershow RC. Among HIV-positive and HIV-negative women. AIDS Patient Care STDS. 2009;23(12):7.

5. Crum-cianflone N, Tejidor R, Medina S, Barahona I, Ganesan A. Obesity among patients with HIV: the latest epidemic *. AIDS Patient Care STDS. 2008;22(12):5. doi:10.1089/apc.2008.0082

6. Semu H, Zack RM, Liu E, et al. Prevalence and risk factors for overweight and obesity among HIV-infected adults in Dar es Salaam, Tanzania. J Int Assoc Provid AIDS Care. 2016;15(6):512-521. doi:10.1177/2325957414542574

7. Kintu A, Liu E, Hertzmark E, et al. Incidence and risk factors for overweight and obesity after initiation of antiretroviral therapy in Dar es Salaam, Tanzania. J Int Assoc Provid AIDS Care Vol. 2018;17(3):110. doi: $10.1177 / 2325958218759759$

8. Biggs C, Spooner E, Obesity GF. HIV: a compounding problem obesity and HIV: a compounding problem. South African J Clin Nutr. 2018;0658(5):5. doi:10.1080/16070658.2017.1404299
9. Guehi C, Badjé A, Gabillard D, et al. High prevalence of being overweight and obese HIV - infected persons, before and after 24 months on early ART in the ANRS 12136 Temprano trial. AIDS Res Ther. 2016;13(4):1-12. doi:10.1186/s12981-016-0094-y

10. Feleke DG, Yemanebrhane N, Gebretsadik D. Nutritional status and CD4 cell counts in HIV/AIDS patients under highly active antiretroviral therapy in addis Ababa, Ethiopia. J AIDS Clin Res. 2017;08 (04):1-4. doi:10.4172/2155-6113.1000688

11. Yemane D, Kinde S, Medhin G, Cherinet Y. Burden of metabolic syndrome among HIV-infected patients in Southern Ethiopia. Diabetes Metab Syndr Clin Res Rev. 2014;8(2):102-107. doi:10.10 16/j.dsx.2014.04.008

12. Loss W, Poirier P, Giles TD, et al. AHA summary statement. Arter Thromb Vasc Biol. 2006;5:968-976. doi:10.1161/01.ATV.0000216 787.85457.f3

13. Poirier P, Eckel RH. Obesity and cardiovascular disease. Curr Atheroscler Rep. 2002;4(Cvd):6.

14. Mathers CD, Loncar D. Projections of global mortality and burden of disease from 2002 to 2030. PLoS Med Proj. 2015;3(11):17. doi:10.1371/journal.pmed.0030442

15. World Health Organization. WHO STEPS instrument for chronic disease; 2009:12. Available from: http://www.who.int/chp/steps/ STEPS_Instrument_v2.1.pdf. Accessed April 4, 2020.

16. Takarinda KC, Mutasa-Apollo T, Madzima B, et al. Malnutrition status and associated factors among HIV-positive patients enrolled in ART clinics in Zimbabwe. BMC Nutr. 2017;3(1):1-11. doi:10. 1186/s40795-017-0132-8

17. Castro ADCO, Silveira EA, Falco MDO, Nery MW, Turchi MD. Overweight and abdominal obesity in adults living with HIV/AIDS Rev Assoc Med Bras. 2016;62(4):353-360. doi:10.1590/1806-9282. 62.04 .353

18. Shayo GA, Mugusi FM. Prevalence of obesity and associated risk factors among adults in Kinondoni municipal district, Dar es salaam Tanzania. BMC Public Health. 2011;11:1-7. doi:10.1186/1471-245811-365

19. Brinkhof MWG, Ph D, Dabis F, et al. Gender and the use of antiretroviral treatment in multicenter collaboration. $J$ Womens Heal. 2008;17(1):47-55. doi:10.1089/jwh.2007.0353

20. Palermo B, Bosch RJ, Bennett K, JM J. Infected men with viral suppression on antiretroviral therapy. HIV Clin Trials. 2012;12 (4):222-227. doi:10.1310/HCT1204-222.Body

21. Frantz JM, Murenzi A. The physical activity levels among people living with human immunodeficiency virus/acquired immunodeficiency syndrome receiving high active antiretroviral therapy in Rwanda. SAHARA J. 2013;10(3-4):113-118. doi:10.1080/17290376. 2014.886081

22. Mashinya F, Alberts M, Colebunders R, Van Geertruyden JP. Weight status and associated factors among HIV infected people on antiretroviral therapy in rural Dikgale, Limpopo, South Africa. African $J$ Prim Heal Care Fam Med. 2016;8(1):1-8. doi:10.4102/phcfm. v8i1.1230

23. Darebo T, Mesfin A, Gebremedhin S. Prevalence and factors associated with overweight and obesity among adults in Hawassa city, southern Ethiopia: a community based cross-sectional study. BMC Obes. 2019;6(1):1-10. doi:10.1186/s40608-019-0227-7 


\section{Publish your work in this journal}

Diabetes, Metabolic Syndrome and Obesity: Targets and Therapy is an international, peer-reviewed open-access journal committed to the rapid publication of the latest laboratory and clinical findings in the fields of diabetes, metabolic syndrome and obesity research. Original research, review, case reports, hypothesis formation, expert opinion and commentaries are all considered for publication. The manuscript management system is completely online and includes a very quick and fair peer-review system, which is all easy to use. Visit http://www.dovepress.com/testimonials.php to read real quotes from published authors. 